\title{
MIR24-2 wt Allele
}

National Cancer Institute

\section{Source}

National Cancer Institute. MIR24-2 wt Allele. NCI Thesaurus. Code C81902.

The human MIR24-2 wild-type allele is located in the vicinity of 19p13.12 and is approximately 72 bases in length. This allele, which encodes MIR24-2 pre-miRNA, plays a role in the regulation of gene expression. Alteration in the expression of this gene is associated with the development of hepatocellular carcinoma. 